\title{
Applicability and Optimal Parameters Analysis for Chemical Phosphorus Removal in a Modified Carrousel Oxidation Ditch
}

DOI: $10.15255 / K U I .2017 .021$

KUI-31/2017

Professional paper Received June 2, 2017 Accepted July 11, 2017

\author{
T. Zhang a,b and Y.-H. Zhao b* \\ a School of Materials Science \& Food Engineering, University of Electronic Science and \\ Technology of China, Zhongshan Institute, Zhongshan, Guangdong, P.R. China \\ bSchool of Resource and Environmental Engineering, Jiangxi University of Science and \\ Technology, Ganzhou, Jiangxi, P.R. China
}

This work is licensed under a Creative Commons Attribution 4.0

\begin{abstract}
\| Abstract
In order to confine the aqua-eutrophication problem arising from phosphorus pollution, many municipal wastewater treatment plants have to improve their executive drainage standard for total phosphorus (TP). In this study, a municipal wastewater treatment plant employing modified Carrousel oxidation ditch as main biological treatment unit was selected as a representative case. Technical necessity for adding a chemically enhanced phosphorus removal unit was analysed, and process feasibility was verified by batch and continuous experiments as well. The study results were summarized as follows. Because the organic carbon source in influent wastewater is not enough, it is impossible to satisfy the national drainage standard of TP by individual biological phosphorus removal processes, therefore, aided chemical phosphorus removal is essential. The polymeric aluminium chloride (PAC) is preferable to be used as precipitant for phosphorus removal. The molar ratio of agent dosage to TP removal is preferable to be about 2.0. Under these conditions, the effluent TP concentration can be lower than $1.0 \mathrm{mgl}^{-1}$.
\end{abstract}

$\|$ Keywords

Wastewater, phosphorus, polyaluminium chloride (PAC), dosage, oxidation ditch

\section{Introduction}

With the development of population and industry in China, a large amount of wastewater containing nitrogen and phosphorus pollutants is discharged into rivers or lakes near cities, which has aroused a series of water pollution problems. As reported in national seashore environment quality of $2015,{ }^{1}$ the major indexes exceeding the national drainage standard were inorganic nitrogen and reactive phosphate, which have led to slight aqua-eutrophication of the seashore. Moreover, sectional monitoring results of 195 rivers emptying into the sea also showed that 58.5 percent of the rivers were inferior to Level III prescribed in surficial aqua-environmental quality standard and the major pollution factors were chemical oxygen demand (COD) and total phosphorus (TP).

As is known, phosphorus is considered a restrictive factor in indispensable nutrients for algae growth and its effects are even more obvious than nitrogen for the eutrophication. ${ }^{2,3}$ In recent years, new drainage standard (GB18918-2002) was put forward by the China government, in which effluents from municipal wastewater treatment plants (WWTPs) should satisfy Class A standard of the first level. However, the large majority of the existing WWTPs could not meet the new standard, so technical renovation towards these WWTPs has become urgent.

A large number of operation cases of the WWTPs have shown that controlling the effluent TP is the most difficult. ${ }^{4}$

* Corresponding author: Dr Yonghong Zhao

e-mail:yh.zhao77@hotmail.com
Although the chemical precipitation method and biological uptake method both can be used to remove the TP from the wastewater, the biological uptake method usually cannot achieve a satisfactory TP removal efficiency because low influent COD has been a universal problem for most of the WWTPs in China. ${ }^{5}$ Besides this, the phosphorus removal is often sacrificed to ensure effective denitrification nitrogen removal at the condition of limited carbon sources in wastewater. ${ }^{6}$ This is because, when compared to nitrogen, phosphorus can be more conveniently and efficiently removed by simple chemical methods.

A municipal WWTP located in Ganzhou, Jiangxi Province, China was often faced with the problem that the discharged TP from the biological treatment process cannot meet the new standard. In view of this, a chemical phosphorus removal unit is considered to be added to enhance the TP removal efficiency. The purpose of this study is to investigate the necessity and applicability of employing the chemical phosphorus removal process to solve the overproof problem of the TP, and to optimize relevant operating parameters for field application. The results of this study may be directive and transplantable to other WWTPs troubled with low efficiency of biological phosphorus removal.

\section{Experimental}

\subsection{Wastewater samples}

The wastewater used in the experiments was sampled from the effluent of the secondary settling tank in the municipal 
WWTP. This municipal WWTP employs a typical secondary treatment process. Modified Carrousel oxidation ditch is used as primary biological treatment unit, which includes three regions, the anaerobic, anoxic, and oxic regions. The biological treatment unit is in fact a front anaerobic region and a subsequent oxidation ditch, in which an individual non-aerated anoxic region is separated. The biological treatment unit can also be considered as a conventional sequential anaerobic/anoxic/oxic $\left(\mathrm{A}^{2} / \mathrm{O}\right)$ process, however, the most obvious difference and advantage is the automatic liquid recirculation between anoxic and oxic regions. The planar structure of the modified Carrousel oxidation ditch can refer to the corresponding part in Fig. 1. Although the WWTP is designed to be able to remove TP by the biological process, its removal ability is not efficient enough to meet the new national drainage standard at present.

After the raw wastewater was acquired, it was filtered by $0.45 \mu \mathrm{m}$ membrane (Nylon), and filtrate was collected and used as experimental raw wastewater samples. The synthesized wastewaters were prepared by adding phosphate buffer $\left(\mathrm{KH}_{2} \mathrm{PO}_{4}\right.$ and $\left.\mathrm{NaOH}, \mathrm{pH}=7.0\right)$ in different quantities to the raw wastewater, and finally formed a series of synthesized wastewater samples with different initial TP concentration.

\subsection{Batch tests}

\subsubsection{Agents selection}

A six coupling mixer was used in these batch tests. Raw municipal wastewater samples of $250 \mathrm{ml}$ were put into a 500$\mathrm{ml}$ beaker and then precipitation agents were added. Initial TP concentration of the samples was $1.76 \pm 0.07 \mathrm{mg} \mathrm{l}^{-1}$. The precipitation agents used included iron(III) sulphate (FS), aluminium sulphate (AS), polymeric iron(III) sulphate (PFS), and polymeric aluminium chloride (PAC), which covered commonly used mono salts and polymeric salts for phosphorus removal. Four different dosages of agents $\left(0.05,0.1,0.15,0.2 \mathrm{mmol} \mathrm{I}^{-1}\right)$ were tested. No pH adjustment was done before adding the precipitation agents. The mixture in the beaker was firstly stirred for $30 \mathrm{~s}$ at a speed of $250 \mathrm{rpm}$ to ensure the rapid dispersion of agents, and then it stirred for another $10 \mathrm{~min}$ at $45 \mathrm{rpm}$. Finally, the mixture in the beaker was transferred to a $250-\mathrm{ml}$ graduated cylinder and put alone to settle for $30 \mathrm{~min}$. The supernatant was reserved in colorimetric tubes for residual TP analysis.

\subsubsection{Sludge production analysis}

Sludge production amount of potential alternative precipitation agents determined by agent selection tests were used. In order to test the sludge production in a wider initial TP concentration range, both raw municipal wastewater and synthesized wastewater samples were used. The initial TP concentration was in the range 1.62-10.47 $\mathrm{mg} \mathrm{l}^{-1}$. Dosage of agents was set according to the requirement ensuring the residual TP concentration was lower than $1.0 \mathrm{mg} \mathrm{I}^{-1}$ and in the range of 0.05 to $0.25 \mathrm{mmoll}^{-1}$. Basic operating processes were the same as described in 2.2.1. After that, wet sludge volume after settling for $30 \mathrm{~min}$ was record- ed and then the mixture including sludge was filtered and dried at $105{ }^{\circ} \mathrm{C}$ to determine the net mass.

\subsubsection{Optimal dosage determination}

The agent used here was the optimal agent selected by the above two procedures in the batch tests. To determine the optimal dosage, raw municipal wastewater and synthesized wastewater samples with different initial TP concentration in the range of 1.82 to $10.44 \mathrm{mgl}^{-1}$ were used. Dosage of agents was set as a continuous varied series in the range of 0.05 to $0.4 \mathrm{mmoll}^{-1}$, in which the last dosage level was just set to ensure the residual TP concentration in supernatant was lower than $1.0 \mathrm{mgl}^{-1}$. Experimental operating processes were exactly the same as in Section 2.2.1.

\subsection{Continuous dosing experiments}

Continuous dosing experiment was directly carried out at the field Carrousel Oxidation Ditch and wet dosing method was adopted. The dosing site can refer to the Section 3.2. The agent used in continuous dosing experiment was the same as that in Section 2.2.3. The agent was firstly dissolved in solution tank as $10 \%$ solution, mixed completely, and pumped into the agent storage tank. The reserved agent was continuously pumped to spraying dosing site, and flow rate of agent solution could be adjusted by a pre-calibrated flow meter. Refer to Fig. 4 for details about the continuous dosing system. Because of the complexity of real-time dosing system, which can vary the flow rate of agent according to the influent TP concentration, it was not used in this study. Three constant flow rates of agent dosing $\left(180 / \mathrm{h}^{-1}, 200 / \mathrm{h}^{-1}, 220 \mathrm{l} \mathrm{h}{ }^{-1}\right)$ were adopted, and each constant flow rate lasted one week. Water samples of the influent and effluent were acquired at 8 am and $6 \mathrm{pm}$ every day, respectively. The influent and effluent wastewater samples were acquired from the oxidation ditch and the secondary settling tank, respectively. The time interval of sampling for the influent and effluent is to match the hydraulic retention time of oxidation ditch.

\subsection{Measurement}

The TP, COD, ammonium, total nitrogen, and mixed liquid suspended solid (MLSS) were measured by ammonium molybdate spectrophotometric, dichromate method, Nessler's reagent spectrophotometric, alkaline potassium persulfate digestion UV spectrophotometric and gravimetric method, respectively. All chemical reagents were purchased from Sinopharm Chemical Reagent Co., Ltd (China). The reagents were AR grade and without further purification before use.

\section{Results and discussion}

\subsection{Technical analysis for current problem}

The influent and effluent water quality and operational MLSS for modified Carrousel oxidation ditch were contin- 
Table 1 - Operational statistical values of modified Carrousel oxidation ditch in a month

\begin{tabular}{|c|c|c|c|c|c|c|c|c|c|}
\hline & \multicolumn{2}{|c|}{$\mathrm{COD} / \mathrm{mgl}^{-1}$} & \multicolumn{2}{|c|}{ ammoniacal nitrogen $/ \mathrm{mgl}^{-1}$} & \multicolumn{2}{|c|}{$\mathrm{TN} / \mathrm{mgl}^{-1}$} & \multicolumn{2}{|c|}{$\mathrm{TP} / \mathrm{mgl}^{-1}$} & \multirow{2}{*}{$\mathrm{MLSS} / \mathrm{mgl}^{-1}$} \\
\hline & Influent & Effluent & Influent & Effluent & Influent & Effluent & Influent & Effluent & \\
\hline average & 123.27 & 15.64 & 28.83 & 4.05 & 29.38 & 11.54 & 3.07 & 2.02 & 3782 \\
\hline standard error & 32.33 & 4.4 & 7.45 & 2.08 & 6.64 & 2.94 & 0.58 & 0.38 & 368 \\
\hline drainage standard & - & 60 & - & 8 & - & 20 & - & 1.0 & - \\
\hline
\end{tabular}

uously sampled and analysed for a month from June 1 to June 30 in 2014. The statistical average values and standard errors are shown in Table 1.

It can be seen from Table 1 that, in the examined month, the effluent from Carrousel oxidation ditch can satisfy the national drainage standard, except for the TP. At present, biological phosphorus removal is not efficient and the average removal efficiency is not above $34.2 \%$. In fact, the low efficiency of TP removal can be predicted by theoretical calculation. If the ratio of BOD to COD is assumed to be 0.65 , then the influent BOD is about $80 \mathrm{mgl}^{-1}$. Because the theoretical carbon source requirement ratio for denitrification is 2.87, about $52 \mathrm{mg} \mathrm{l}^{-1}$ BOD was consumed by denitrification nitrogen removal process. ${ }^{7}$ Maximum residual BOD for phosphorus removal is $28 \mathrm{mg} \mathrm{l}^{-1}$, then the $\mathrm{BOD} / \mathrm{TP}$ is lower than 9 , which is far from enough for TP removal. In fact, the majority of the influent COD will be consumed by heterotrophic bacteria in the aeration stage, so the available carbon source for biological phosphorus removal will be much less. Therefore, the low TP removal efficiency can be attributed to the fact that the influent organic carbon source is insufficient. However, the influent wastewater contents are relatively steady and impossible to increase substantially for years. In order to guarantee the effluent TP to satisfy the drainage standard, supplementary chemical phosphorus removal is an inevitable choice.

\subsection{Dosing site selection}

According to location relationship with the biological unit, the dosing site of chemical phosphorus removal agents can be classified into three types, i.e., prepositive, simultaneous, and postpositive chemical phosphorus removal. ${ }^{8}$ Possible dosing sites in this WWTP are shown in Fig.1.

Carrousel oxidation ditch

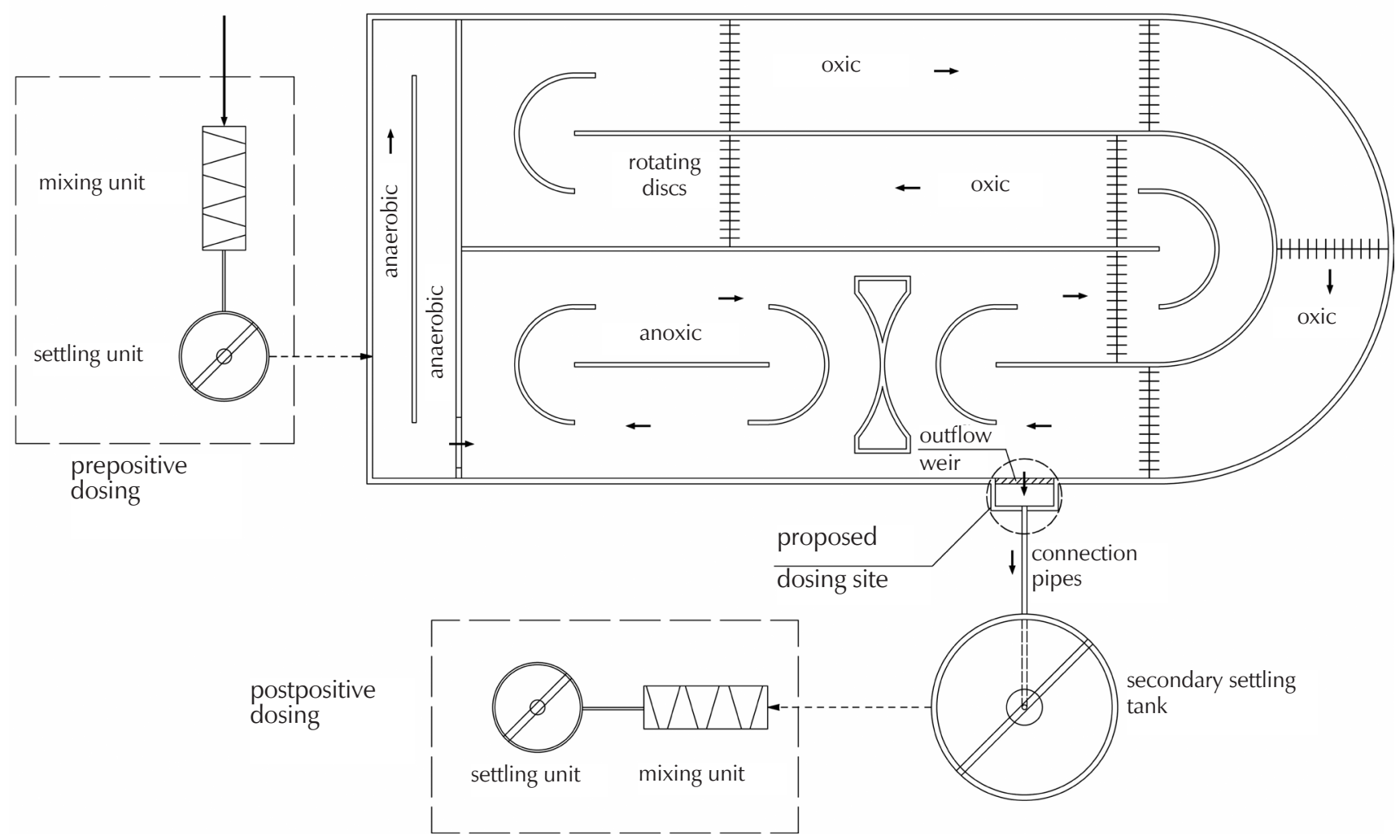

Fig. 1 - Possible dosing sites in this wastewater treatment plant 
Taking into consideration that the primary settling tank is not constructed in this WWTP, and if the prepositive phosphorus removal process is adopted, independent settling tank should be required to separate the phosphate precipitate and extra construction investment should be added. Similarly, if the postpositive phosphorus removal process is adopted, a new settling unit or large investment should also be supplemented. On the contrary, simultaneous phosphorus removal may be an appropriate choice. The phosphorus removal agents can be dosed at outflow weir of the oxidation ditch by multi-point spraying method. The dosed agents can be hydraulically mixed with the wastewater by energy dissipation of water fall, resulting from down-flow water from the outflow weir. Subsequently, flocculation process can take place in the connection pipes between oxidation ditch and secondary settling tank by hydraulic turbulence fluctuation. Finally, separation of phosphate precipitate can be accomplished in the secondary settling tank. If so, not only can a large-scale construction investment be saved, but also all the required sub-procedures for chemical phosphorus removal, such as mixing, flocculation and settling, can be masterly fulfilled. According to the above analysis, simultaneous chemical phosphorus removal process, selecting outflow weir of the oxidation ditch as agent dosing site may be the most reasonable, which is economical and feasible.

\subsection{Batch test for chemical phosphorus removal}

\subsubsection{Comparison of removal efficiency for different agents}

Conventional chemical phosphorus removal agents include two classes, aluminium salts and iron(III) salts. ${ }^{9}$ In recent years, when compared with inorganic mono salt, inorganic polymeric salts have been demonstrated to have some advantages, such as rapid flocs generation, high flocs density, high settling velocity, and powerful adaptive ability to water quality. ${ }^{10}$ Fig. 2 shows the results of removal efficiency for different precipitation agents.

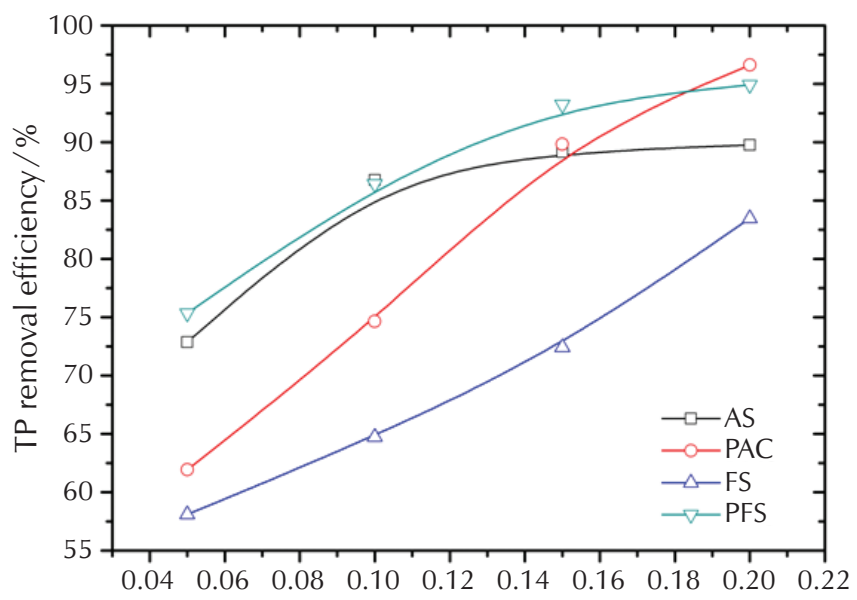

Fig. 2 - TP removal efficiency for different precipitation agents

It can be seen that: (1) when precipitation agents concentration is not above $0.1 \mathrm{mmoll}^{-1}$, AS and PFS have higher
TP removal efficiency, but PFS and PAC have higher removal efficiency above $0.15 \mathrm{mmol}^{-1}$. (2) The removal efficiency of FS is relatively low in the experimental range. (3) The variation trend for curves of AS and PFS is more similar with the logarithm function rule, but in the experimental range, the removal efficiency by PAC almost linearly increases with the increasing dosage and reaches $96.6 \%$ when dosage is $0.2 \mathrm{mmol} \mathrm{I}^{-1}$. If the TP removal efficiency is required to be above $90 \%$, the PAC and PFS both can be alternatives and the needed dosage has no obvious difference. However, the TP removal efficiency for the mono salts AS and FS are relatively low. Therefore, further selection should be made to compare the PAC and PFS.

\subsubsection{Sludge production amount of different agents}

In general, sludge production is the most unfavourable characteristic for precipitation process. Therefore, it is necessary to find an appropriate precipitation agent producing minimum sludge if the precipitation process is indispensable. The amount of sludge production using the PAC and PFS is shown in Fig. 3.
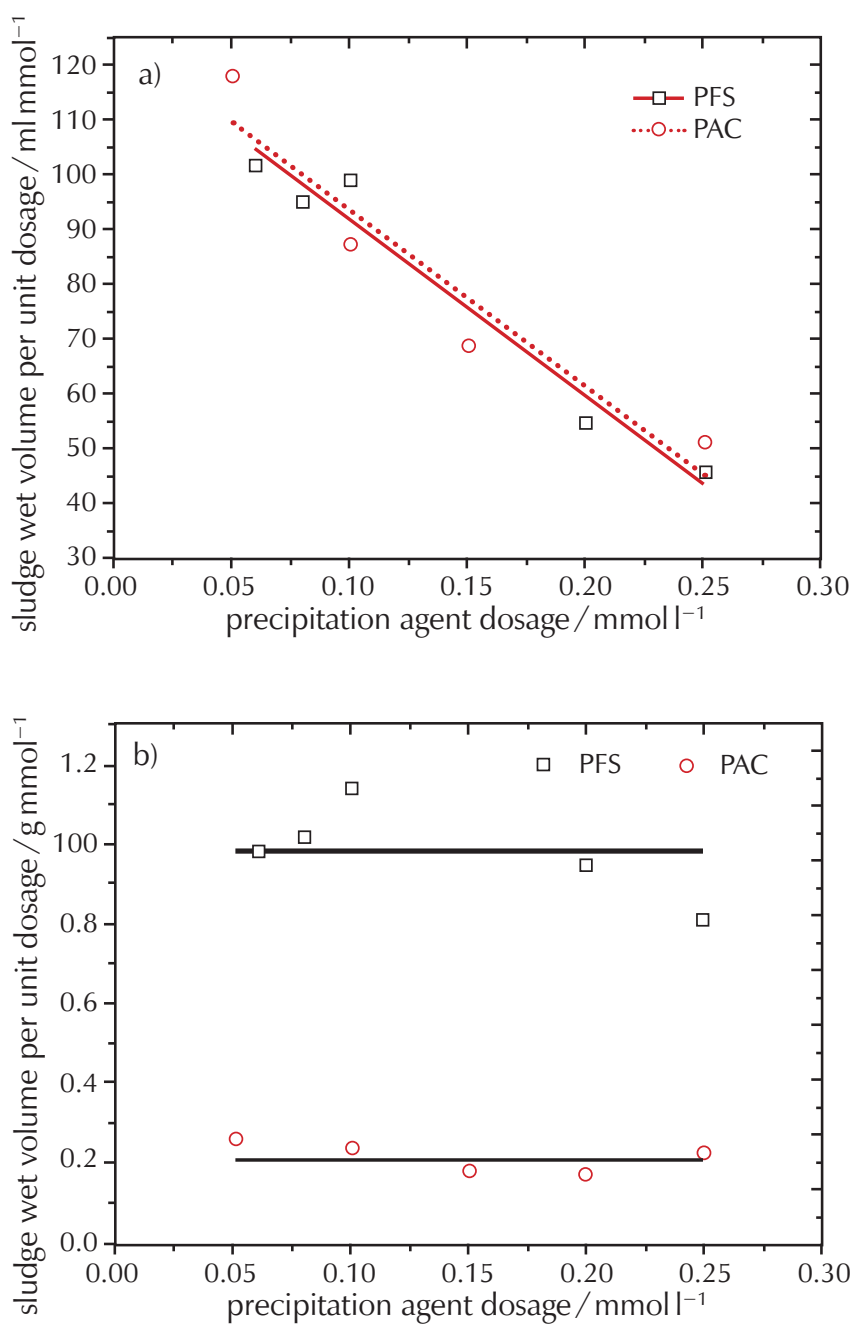

Fig. 3 -Comparison of sludge production amount: a) wet volume; b) dry mass 
Table 2 - Molar ratio of Al/TP for phosphorus removal by PAC

\begin{tabular}{|c|c|c|c|c|c|c|c|c|}
\hline \multirow{3}{*}{$\begin{array}{c}\mathrm{TP} \text { in raw } \\
\text { wastewater } \\
/ \mathrm{mgl}^{-1}\end{array}$} & \multicolumn{8}{|c|}{ PAC dosage $/ \mathrm{mmoll}^{-1}$} \\
\hline & 0.05 & 0.1 & 0.15 & 0.2 & 0.25 & 0.3 & 0.35 & 0.4 \\
\hline & \multicolumn{8}{|c|}{ Amount of substance ratio of Al to TP } \\
\hline 1.82 & 1.38 & - & - & - & - & - & - & - \\
\hline 3.64 & 1.19 & 1.63 & 1.78 & 2.11 & - & - & - & - \\
\hline 4.45 & 1.02 & 1.54 & 1.62 & 1.88 & 2.14 & - & - & - \\
\hline 6.59 & 0.94 & 1.43 & 1.68 & 1.74 & 1.77 & 1.78 & 1.84 & - \\
\hline 8.37 & 0.84 & 1.02 & 1.18 & 1.23 & 1.41 & 1.53 & 1.57 & - \\
\hline 10.44 & 0.82 & 0.93 & 0.99 & 1.12 & 1.21 & 1.24 & 1.29 & 1.35 \\
\hline
\end{tabular}

Fig. 3a gives the wet volume of the produced sludge per unit precipitation agent dosage, and no obvious difference can be observed for the wet volume of sludge produced by PFS and PAC. The wet volume for PAC is only slightly higher than that of PFS at the same dosage. However, as shown in Fig. 3b, the average dry mass of the produced sludge per unit precipitation agent dosage differs significantly. At experimental dosage range, the average value of sludge dry mass for PFS is $0.98 \mathrm{~g}$ every millimole agent dosage, but this value for PAC is only 0.21 , which is nearly one-fifth of the PFS'. The reason may be that the density of the ferric precipitation is much higher than that of the aluminium. Therefore, in view of producing less precipitation quantity, the PAC may be more suitable for chemical phosphorus removal than PFS.

\subsubsection{Optimal dosage determination}

In order to reduce the cost of adding agents, the dosage should be minimized at the prerequisite of satisfactory TP removal destination. Molar ratio of dosage to removal (MRDR) of TP was employed as a critical parameter to characterize the precipitation consumption per unit TP removal. At a series of initial TP concentration and different PAC dosages, the MRDR was calculated, as listed in Table 2.

From the data in Table 2, the following can be concluded: (1) For wastewater sample with the same concentration, more PAC is used, the MRDR increases, i.e., more agent is consumed for unit TP removal or TP removal efficiency decreased with increasing dosage. (2) Using the same dosage for wastewater samples with different initial TP concentration, the higher the initial TP concentration, the lower the MRDR changes, i.e., the TP removal efficiency increases with the increasing initial TP concentration. This can be explained by the collision-reaction theory of particles. For example, the higher TP concentration in raw wastewater represents larger number density of objective particles. If the PAC is considered as attacking particles, at the same number density of attacking particles, then precipitation reaction velocity is determined by the number density of objective particles, or high TP initial concentration is beneficial for low MRDR value. In a similar way, if the number density of objective particles or initial TP concentration is the same, low number density of attacking particles can lead to a high collision possibility, so low dosage is favourable to ensure a low MRDR value.

Meanwhile, the following Table 3, which is probability statistical results of MRDR distribution, can be derived from Table 2.

Table 3 - Probability statistical distribution of MRDR ensuring the drainage standard

\begin{tabular}{l|c|c|c|c|c}
\hline $\begin{array}{l}\text { MRDR } \\
\text { value }\end{array}$ & $\leq 1.0$ & $\leq 1.5$ & $\leq 1.8$ & $\leq 2.0$ & $\leq 2.2$ \\
\hline $\begin{array}{l}\text { distribution } \\
\text { number/total } \\
\text { number }\end{array}$ & $5 / 32$ & $18 / 32$ & $28 / 32$ & $30 / 32$ & $32 / 32$ \\
& & & & & \\
$\begin{array}{l}\text { distribution } \\
\text { probability } / \%\end{array}$ & $15.6 \%$ & $56.2 \%$ & $87.5 \%$ & $93.8 \%$ & $100 \%$ \\
\hline
\end{tabular}

It can be seen from Table 3 that, in the experimental range, when the MRDR is set as high as 2.0, the probability for ensuring the effluent TP to be lower than $1.0 \mathrm{mgl}^{-1}$ can reach up to $93.8 \%$, and $100 \%$ when MRDR is 2.2. Because the experimental times are not fewer, so the statistical results can be reliable to some extent. In this sense, to guarantee the effluent TP is not higher than $1.0 \mathrm{mgl}^{-1}$ at the reliability of $90 \%$, setting the MRDR value between $1.8 \sim 2.0$ is reasonable. 


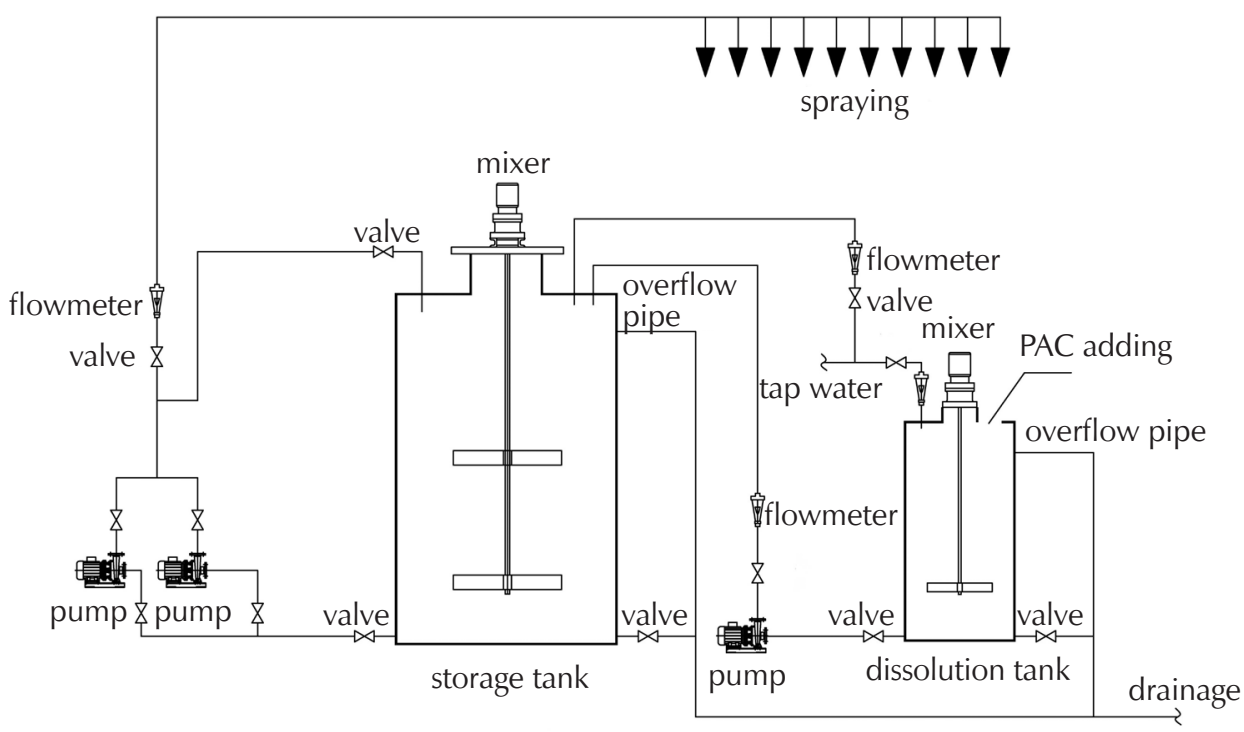

Fig. 4 - Schematic of continuous experimental system

Table 4 - Continuous agent dosing experimental results

\begin{tabular}{|c|c|c|c|c|c|c|c|c|}
\hline Periods & \multicolumn{8}{|c|}{ Results } \\
\hline \multirow{4}{*}{1} & \multirow{2}{*}{$\begin{array}{l}\text { flow rate } \\
\text { influent } \mathrm{TP} / \mathrm{mgl}^{-1}\end{array}$} & \multicolumn{7}{|c|}{$180 \mathrm{Ih}^{-1}$} \\
\hline & & 1.573 & 1.534 & 1.613 & 1.455 & 1.436 & 1.711 & 1.652 \\
\hline & effluent $\mathrm{TP} / \mathrm{mgl}^{-1}$ & 0.846 & 0.708 & 0.924 & 0.806 & 0.787 & 0.826 & 0.806 \\
\hline & MRDR & 2.2 & 1.9 & 2.3 & 2.0 & 1.9 & 1.8 & 1.9 \\
\hline \multirow{4}{*}{2} & flow rate & \multicolumn{7}{|c|}{$200 \mathrm{Ih}^{-1}$} \\
\hline & influent $\mathrm{TP} / \mathrm{mgl}^{-1}$ & 1.809 & 1.908 & 1.75 & 2.08 & 1.731 & 1.632 & 1.789 \\
\hline & effluent $\mathrm{TP} / \mathrm{mgl}^{-1}$ & 0.964 & 0.924 & 0.865 & 1.141 & 0.786 & 0.747 & 0.983 \\
\hline & MRDR & 2.1 & 1.8 & 2.0 & 1.9 & 1.9 & 2.0 & 2.2 \\
\hline \multirow{4}{*}{3} & flow rate & \multicolumn{7}{|c|}{$220 \mathrm{Ih}^{-1}$} \\
\hline & influent $\mathrm{TP} / \mathrm{mgl}^{-1}$ & 1.593 & 1.495 & 1.278 & 1.416 & 1.337 & 1.475 & 1.495 \\
\hline & effluent $\mathrm{TP} / \mathrm{mgl}^{-1}$ & 0.846 & 0.747 & 0.708 & 0.885 & 0.727 & 0.806 & 0.924 \\
\hline & MRDR & 1.7 & 1.7 & 2.1 & 1.9 & 2.0 & 1.8 & 2.1 \\
\hline
\end{tabular}

\subsection{Continuous dosing experiments}

In order to verify the results acquired by the batch tests, continuous agent dosage experimental system was designed and developed at the WWTP. According to the above discussion, PAC is suitable to be used as phosphorus removal agent in this experiment. The schematic of the continuous system is shown in Fig. 4. Continuous experimental results are shown in Table 4.

Despite the continuous variation of influent TP concentration each day, the effluent TP concentration could be steadily lower than $1.0 \mathrm{mgl}^{-1}$ in total experimental periods of 21 days except for one day. The MRDR value for the continuous dosing experiments had no obvious difference with that of the batch tests, and average value was below 2.0. This proves that chemical phosphorus removal by PAC is very efficient and can achieve steady TP drainage satisfying the national standard at field conditions of wastewater quality.

\section{Conclusion}

In order to solve the excessive drainage problem of TP in the WWTP, applicability of chemical phosphorus removal and optimal analysis of operating parameters have been conducted. One month of monitoring data reveals that low TP removal efficiency can be attributed to the lack of organic carbon source in influent wastewater. At this condition, chemical phosphorus removal is a necessary choice to guarantee the steady drainage up to the standard. Outflow weir of modified Carrousel oxidation ditch is a reasonable dosing site for precipitation agent. Batch tests show that PAC is suitable to be used as phosphorus removal agent, and controlling the MRDR value between 1.8-2.0 is optimal. Continuous dosing experiments demonstrate that chemical phosphorus removal process is applicable for practical wastewater quality, and can ensure steady TP drainage up to the national standard of China. 


\section{ACKNOWLEDGEMENTS}

This research is financially supported by the National Natural Science Foundation of China (No. 21406096), the Program of Youth Science Foundation of Jiangxi Province (No. 20142BAB213022), scientific research foundation of University of Electronic Science and Technology of China, Zhongshan Institute (415YKQ07), and science and technology project in Zhongshan (2015B2322).

\section{List of symbols and abbreviations}

$\begin{array}{ll}\text { A }^{2} / \mathrm{O} & \text { - anaerobic/anoxic/oxic } \\ \text { AS } & \text { - aluminium sulphate } \\ \text { BOD } & \text { - biological oxygen demand } \\ \text { COD } & \text { - chemical oxygen demand, } \text { mgl }^{-1} \\ \text { FS } & \text { - iron(III) sulphate } \\ \text { MLSS } & \text { - mixed liquid suspended solid } \\ \text { MRDR } & \text { - molar ratio of dosage to removal } \\ \text { PAC } & - \text { polymeric aluminium chloride } \\ \text { PFS } & - \text { polymeric iron(III) sulphate } \\ \text { TN } & - \text { total nitrogen } \\ \text { TP } & - \text { total phosphorus } \\ \text { WWTP } & - \text { wastewater treatment plant }\end{array}$

\section{References Literatura}

1. Ministry of environmental protection of the People's Republic of China, Bulletin of environmental quality in the coastal water of China, 2015, 8.

2. R. Ramaraj, D. D.W Tsai, P. H. Chen, Carbon dioxide fixation of freshwater microalgae growth on natural water medium, Ecol. Eng. 75 (2015) 86-92, doi: https://doi.org/10.1016/j. ecoleng.2014.11.033.

3. W. Dodds, V. H. Smith, Nitrogen, phosphorus, and eutrophication in streams, Inland Waters 6 (2016) 155-164, doi: https://doi.org/10.5268/IW-6.2.909.

4. J. Y. Wu, Q. J. Liu, H. G. Si, G. J. Lei, Case analysis of the chemical dephosphorization project by pre-anaerobic oxidation ditch, Ind. Water Treat. (China) 35 (2015) 103-105.

5. K. Fytianos, E. Voudrias, N. Raikos, Modelling of phosphorus removal from aqueous and wastewater samples using ferric iron, Environ. Pollut. 101 (1998) 123-130, doi: https://doi. org/10.1016/S0269-7491(98)00007-4.

6. R. B. Wang, J. Li, N. Zhang, Development of biological phosphorus removal in wastewater treatment process, Environ. Eng. (China) 25 (2007) 84-88.

7. Y. M. Xie, Introduction to environmental water quality model, China Sci. Technol. Publ. House, Beijing, 1996, pp. 127 129.

8. G. H. Michael, Chemical Phosphorus Removal, in Troubleshooting the Sequencing Batch Reactor, John Wiley \& Sons, Inc., 2010.

9. T. Clark, T. Stephenson, P. A. Pearce, Phosphorus removal by chemical precipitation in a biological aerated filter, Wat. Res. 31 (1997) 2557-2563, doi: https://doi.org/10.1016/S00431354(97)00091-2.

10. J. Q. Jiang, N. J. D. Graham, Pre-polymerised inorganic coagulants and phosphorus removal by coagulation-a review, Water SA 24 (1998) 237-244.

\section{SAŽETAK \\ Kemijsko uklanjanja fosfora u karuselskom oksidacijskom kanalu i analiza optimalnih parametara \\ Tao Zhang ${ }^{\mathrm{a}, \mathrm{b}}$ i Yonghong Zhao b*}

Mnogi mjestni pogoni za pročišćavanje vode moraju poboljšati uklanjanje ukupnog fosfora (TP) radi smanjenja eutrofikacije voda. Ovdje je prikazano postrojenje za pročišćavanje vode s karuselskim oksidacijskim kanalom. Istraženi su tehnički zahtjevi za poboljšano kemijsko uklanjanje fosfora, a proces je ocijenjen prema šaržnim i kontinuiranim eksperimentima. Budući da nedostaje organskog ugljika, ne može se zadovoljiti standard uklanjanja ukupnog fosfora samo biološkim putem. Nužan je kemijski postupak za koji je pogodno taložno sredstvo polimerni aluminijev klorid (PAC). Najbolji množinski omjer sredstva za obradu vode i TP-a je oko 2,0. Pri takvim uvjetima izlazna koncentracija TP-a može biti niža od $1,0 \mathrm{mgl}^{-1}$.

Ključne riječi

Otpadna voda, fosfor, polimerni aluminijev klorid (PAC), doziranje, oksidacijski kanal

a School of Materials Science \& Food

Engineering, University of Electronic Science and Technology of China, Zhongshan Institute,

Zhongshan, Guangdong, Kina

b School of Resource and Environmental

Engineering, Jiangxi University of Science and

Technology, Ganzhou, Jiangxi, Kina
Stručni rad

Prispjelo 2. lipnja 2017.

Prihvaćeno 11. srpnja 2017. 